\title{
Structural changes in the rural economy
}

\author{
Landysh Sitdikova ${ }^{1, *}$, Farida Mukhametgalieva ${ }^{1}$, Farit Mukhametgaliev $^{1}$ and Akmaral Zh. Bukharbayeva ${ }^{2}$ \\ ${ }^{1}$ Kazan State Agrarian University, Kazan, 420015, Russia \\ ${ }^{2}$ Korkyt Ata Kyzylorda State University, Kyzylorda, 120001, Kazakhstan
}

\begin{abstract}
The relevance of the topic is due to the need to study features of the rural economic development in the current social and economic environment. The aim of the article is to develop recommendations for improving the efficiency of rural business by analyzing the current situation and identifying features of development of agricultural businesses. The article describes results of an analysis of characteristics of the development of sectors of the rural economy over the past seven years. It has been established that the annual growth rates of the economy of the Republic of Tatarstan in general and the agricultural sector, in particular, are decreasing. In the next five years, they may amount to only $1-1.5 \%$; in 2014-2016, GRP of the agricultural sector amounted to 11-12\%, in 2017-2019 - 10\%. According to the existing trend, its share may decline to $8-9 \% ; 50 \%$ of the production volume are produced by small businesses, which have a strong influence on volume indicators and are characterized by growth instability depending on demand and price fluctuations in the market. It is necessary to create conditions for the stable functioning of large agricultural producers, take measures to create a system of agricultural consumer cooperatives and diversify the rural economy in order to achieve stable development of rural territories.
\end{abstract}

\section{Introduction}

The rural economy is one of the drivers for the development of rural territories and regions of Russia, as it performs social functions, such as providing the population with food and supporting the employment of society. The problems of the rural economy and changes in its structure are of particular interest. It is one of the priority national projects. It is necessary to develop rural territories. [1,2].

The effectiveness of measures implemented in rural areas depends on the conditions for the effective development of a variety of forms of management and activities. Among the various forms of farming, peasant (farmer) farms play an important role. They are small businesses, personal farms, agricultural cooperatives. Studies aimed at analyzing the current state of activities of agricultural businesses, identifying conditions for their functioning, reserves for the development of alternative forms are relevant.

\section{Materials and Methods}

The theoretical and methodological base of the study is the use of a possibility of interaction of fundamental principles, the economic theory, works by foreign and domestic agricultural economists, normative and legislative acts of the Russian Federation on the agrifood policy, materials of international and all-Russian scientific and practical conferences devoted to the development of agriculture.
The general methodological basis of the study is a system analysis. The vast material made it necessary to use various approaches, methods and techniques for the study of socio-economic processes, such as constructive, deterministic, retrospective, dynamic, statistical. The methods were used to reveal trends of the agri-food policy and their peculiarities: monographic, abstractlogical, computational-constructive, economic-statistical, analogies.

Statistical data from the official websites of the Federal State Statistics Service of the Russian Federation, Federal Ministries of the Russian Federation, Regional Ministries of the Republic of Tatarstan, annual reports of enterprises of the agro-industrial complex, materials contained in monographs, dissertations, reports of research institutes, in publications, materials of scientific conferences, expert assessments, data obtained during the author's analysis and calculations were used as an informational and factual source of research.

\section{Results}

The Republic of Tatarstan (RT) is among the three regions of the Russian Federation with the largest gross agricultural product; it provides the population with own food products. The republic occupies a land area of 6.8 million hectares, of which agricultural land is 4.5 million hectares, including 3.4 million hectares of arable land. The number of population is 3896.5 thousand, the average annual number of people employed in the economy is 1952 thousand, of which the number of

\footnotetext{
Corresponding author: sitdikovalandysh@mail.ru
} 
workers employed in the agricultural sector is 170 thousand, which is $8.7 \%$ of the population of the republic.

Agricultural production is represented by 458 agricultural organizations, 4,263 peasant farms, 273 agricultural consumer cooperatives, 455 thousand personal subsidiary plots. In 2019, the volume of the gross regional product amounted to 2464.7 billion rubles, with a growth rate of $1.0 \%$ compared to the previous year. A significant share is produced by industries, agriculture and trade $[3,4]$.

The share of agriculture is 10.1. In 2019, the agricultural output increased by $3.0 \%$ in comparable prices to the level of 2018 and amounted to 250.9 billion rubles. The agriculture is developing, which is facilitated by the natural and climatic conditions, state support, large investments, etc. Nowadays, occupying $2.3 \%$ of
Russia's agricultural land, the Republic of Tatarstan produces $4.6 \%$ of the agricultural sector of the country's economy. In full, it provides its population with food and has the ability to increase the supply of agricultural products for export [5-7].

The Republic of Tatarstan ranks among the leading regions of the Russian Federation by the main macroeconomic indicators. In terms of gross regional product, the Republic of Tatarstan ranks sixth, and by the agricultural gross product, it ranks third. The imports of agricultural products is minimal; mainly drinks and breeding animals are imported (poultry $-30 \%$ and cattle $-60 \%$ ).

Agriculture is an important sector of the economy of Tatarstan. The dynamics of the growth rate of the gross regional product (GRP) and the cost of gross agricultural product for 2013-2019 is presented in Fig. 1 [7, 8].

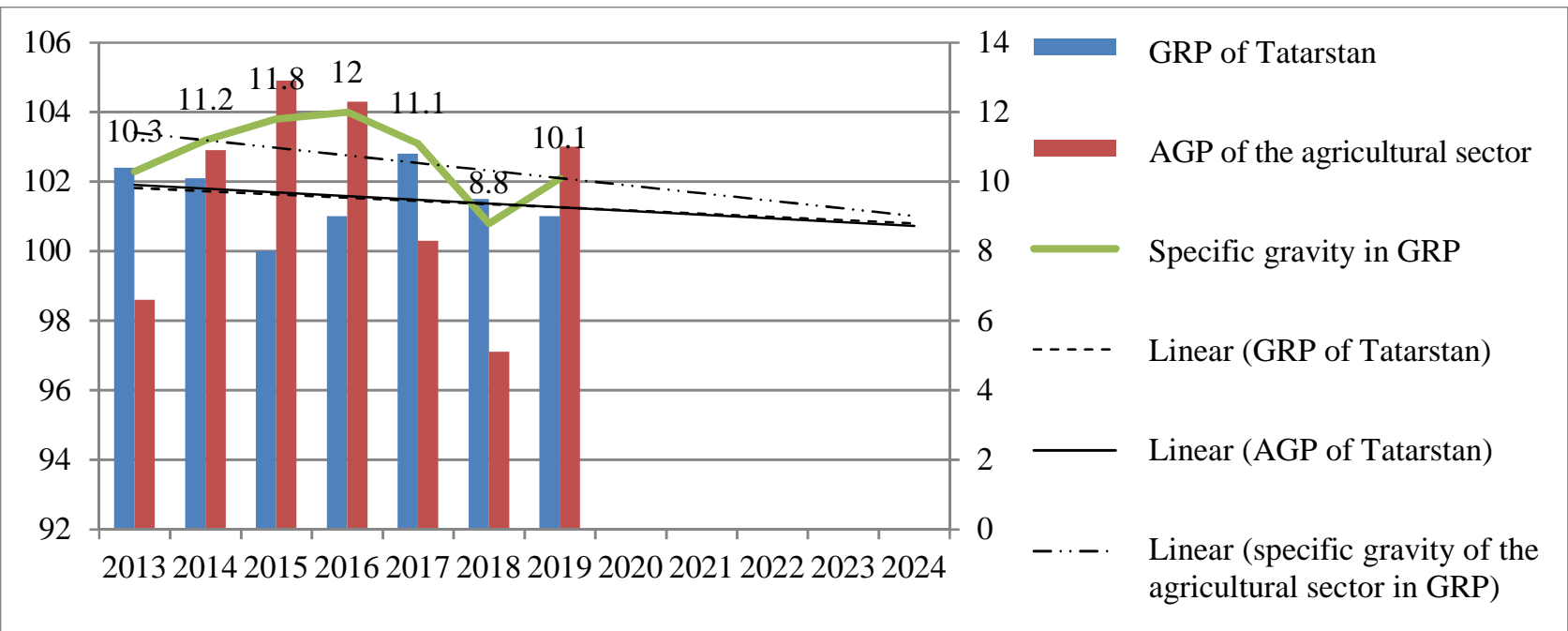

Fig. 1. Dynamics of GRP growth rates, the value of gross agricultural product and specific weight of agriculture in the structure of the GRP of Tatarstan for 2013-2019.

The dynamics of GRP growth rates and the value of gross agricultural product has a tendency to slow down. Their trend lines almost coincide. Over the next 5 years, the positive dynamics of production growth is maintained with an average annual growth rate of 1-1.5 percent. But in accordance with the development strategy of the Republic of Tatarstan until 2030, where the annual growth rate of 5 percent is set, this is not sufficient $[9,10]$.

Against the background of the general development of the economy, the share of agriculture in the structure of the GRP of Tatarstan tends to decrease. On the one hand, much attention is paid to the development of the IT industry, petrochemical processing enterprises, construction businesses, and service enterprises. It becomes more difficult for agriculture, as one of the capital-intensive industries, requiring large investments, to compete with industries.

According to the current trend, the share of agriculture can drop to $8-9 \%$ in the next five years, compared to $11-12 \%$ in 2014-2016. The peculiarity of the situation is that the growth rates of the economy of Tatarstan and the agricultural sector are declining, which requires measures to intensify industrial and entrepreneurial activities in the real economy, especially in the agricultural sector to ensure sustainable development of the rural economy and business activities in rural areas.

An analysis of the cost indicators of agricultural production (private farms, peasant farms, large agricultural organizations) shows that in 2019, the production volume increased by $3 \%$, including in large agricultural organizations - by $5.2 \%$, in peasant farms by $20.0 \%$, while in the private farms this indicator decreased by $2.9 \%$. (Table 1 ) [7.8].

In 2019, the production structure was as follows: large agricultural organizations produced $49.9 \%$ of agricultural products, private households $-40 \%$, and peasant farms $-10.1 \%$. The agricultural production growth rate indices show large agricultural market players have stable indicators, i.e., they maintain their niche and are not subject to sharp changes in the production structure and volumes. Half of the produces are produced by small businesses. Peasant farms show high growth rates, but they occupy only $10.1 \%$ and their results do not affect the overall growth rate. Households 
have a strong influence on volume indicators, but they are characterized by instable growth, as the most mobile market players, changing supply depending on demand and price fluctuations. In this regard, it is necessary to ensure the stable functioning of large agricultural producers, create conditions for stable development of peasant and private farms [6].

In general, the agrarian sector of the republic's economy is profitable. The exception is the traditionally unprofitable beef production industry. It should be noted that the level of profitability of agricultural industries is not high, amounting to no more than $10-12 \%$, which limits the possibilities for expanded reproduction based on the re-equipment of agriculture with the latest achievements of science and technology.
The main performance indicators of large agricultural organizations are presented in Table $2[7,8]$.

Table 1. Indices of agricultural production by categories of farms (in comparable prices; in percent to the previous year)

\begin{tabular}{|c|c|c|c|c|}
\hline \multirow{2}{*}{ Years } & \multirow{2}{*}{ Farms } & \multicolumn{3}{|c|}{ including } \\
\cline { 3 - 5 } & & $\begin{array}{c}\text { agricultural } \\
\text { organizations }\end{array}$ & households & $\begin{array}{c}\text { peasant } \\
\text { farms }^{2}\end{array}$ \\
\hline $2014^{1)}$ & 103.2 & 106.5 & 98.3 & 118.6 \\
\hline $2015^{1)}$ & 104.1 & 105.0 & 102.1 & 110.3 \\
\hline $2016^{1)}$ & 104.9 & 104.3 & 103.8 & 115.4 \\
\hline $2017^{1)}$ & 104.9 & 109.6 & 97.0 & 119.5 \\
\hline 2018 & 97.0 & 92.6 & 103.1 & 91.1 \\
\hline 2019 & 103.0 & 105.2 & 97.1 & 120.0 \\
\hline
\end{tabular}

${ }^{1)}$ Data recalculated based on the results of the 2016 AllRussian Agricultural Census.

${ }^{2)}$ Including individual entrepreneurs.

Table 2. The financial results of activities of agricultural organizations of the Republic of Tatarstan

\begin{tabular}{|l|c|c|c|c|c|c|c|}
\hline \multirow{2}{*}{ Parameters } & \multicolumn{3}{c|}{ Years } & \multicolumn{2}{c|}{} \\
\cline { 2 - 7 } & 2013 & 2014 & 2015 & 2016 & 2017 & 2018 & 2019 \\
\hline Number of households, units & 486 & 427 & 442 & 493 & 486 & 463 & 458 \\
\hline including profitable, units & 383 & 392 & 401 & 455 & 443 & 425 & 423 \\
\hline share of profitable, \%. & 78.8 & 91.8 & 93 & 92 & 91 & 92 & 92 \\
\hline unprofitable, units & 103 & 35 & 41 & 38 & 43 & 38 & 35 \\
\hline specific weight of unprofitable, \% & 21.2 & 8.2 & 7 & 8 & 9 & 8 & 8 \\
\hline The amount of untaxed profit, mln. rub. & 2571 & 9835 & 12682 & 7755 & 7934 & 8827 & 9366 \\
\hline Profitability, \% & 4.5 & 16.2 & 17.4 & 9.4 & 9.6 & 10.1 & 9.8 \\
\hline Target financing and budget revenues, mln. rub. & 12306 & 9837 & 13642 & 11662 & 10261 & 9581 & 8325 \\
\hline share of budget revenues in cash revenue, \% & 21.1 & 15.8 & 16.7 & 12.7 & 11.5 & 10.3 & 7.9 \\
\hline
\end{tabular}

Recently, agricultural organizations are being enlarged; as a result, their total number is declining. During the analyzed period, the number of farms in the agricultural sector decreased by 28 units due to the joining of weak organizations to stronger ones. The number of efficiently operating organizations remains at the same level and in 2019, out of 458 farms, 423 (92\%) completed their activities with a profit. In this direction, the state regulation of the agrarian economy has a significant impact by providing targeted support, which contributes to ensuring the profitable activity of farms at the level of $10 \%$.

The data indicate that without state participation in financing the agricultural business, farms would be unprofitable [11]. Nevertheless, agricultural organizations show stable performance, avoiding sharp breakdowns and failures. It is necessary to create conditions for the efficient use of the production potential and advantages of the large agricultural industry. The main problem is the low level of profitability of workers engaged in agricultural production. It amounted to 23,560 rubles per month in 2019 (64.4\% of the average salary in the country). A feature of labor motivation is the relatively low wages.

Over the past seven years, the average annual number of employees has decreased from 70.7 to 43.3 thousand people. The strengthening of large-scale production had a positive effect on labor productivity and caused the mass departure of agricultural workers to small and private farms. Small commodity production, based on primitive technologies, is not able to ensure high profitability of labor of the rural population and attractiveness of the rural lifestyle. This is not a good scenario for the development of the rural economy. It slows down the solution of the national food security problem and creates social problems: high unemployment, low living standards and excessive pressure on labor markets in cities.

A significant drawback is that small farms, although they produce about half $(47.3 \%)$ of all agricultural products in Russia, and more than half $(51.2 \%)$ of agricultural products in the Republic of Tatarstan, are not able to store, process and to sell their products at reasonable market prices. They are forced to sell their products at prices below market ones [12]. They are not united to protect their interests. With the provision of certain assistance from the state and regional authorities, small businesses can unite by forming various types of agricultural consumer cooperatives. They improve the food supply, protect their interests in the market, and improve the living standards of members of the cooperative.

The government is taking measures to develop agricultural consumer cooperatives and provide them with financial support. The Republic of Tatarstan has adopted a special program for the development of such cooperatives, in accordance with which work aimed at ensuring active participation of farmers and agricultural organizations in the market economy is performed. However, this process is very slow and difficult due to deficiencies in legal, financial and material relations. Only $2 \%$ of the farmers are members of cooperatives.

A significant increase in the volume of financial support is required, since the formation of the material 
and technical base is expensive. Such a measure will make it possible to use grant support to a larger number of agricultural consumer cooperatives. At the municipal level, there are flaws in the development of small businesses. The budget of some municipal districts either does not include specific amounts of financing or they do not even reach $1 \%$ of the expenditures.

To increase the efficiency of the rural economy, it is necessary to restructure its structure based on the formation of effective operating entrepreneurial structures for joint production, processing and sale of agricultural products. In order to preserve and develop rural areas, it is necessary to conduct an audit (inventory) of the resources of rural settlements, determine the availability of land, labor, material and technical resources to create small and medium businesses.

Given the periodic and seasonal nature of agricultural labor, it is necessary to develop alternative activities that ensure full employment and replenish budget revenues. The main areas are as follows. 1. creation of le-industrial clusters in rural areas, including several business groups: logging, leasing forest land and harvesting; production bases for storage and primary processing of wood, woodworking workshops, construction cooperatives, brigades, trade and exhibition complexes of wood processing products. 2. creation of construction and repair clusters in rural areas, including enterprises that perform works at various stages of construction and repair: brick, concrete plants, workshops producing plastic windows, insulation, wallpaper, building mixtures, paints, construction equipment, tools, metal tiles, etc. 3. Development of the agritourism, hotels, restaurants, cafes and canteens. 4. creation of workshops producing furniture, interior and exterior doors. 5. creation of logistics centers, freight transport enterprises. 6. development of the rural industry manufacturing plastic products, clothes, electric tools and household appliances.

\section{Conclusion}

The rural economy of the Republic of Tatarstan shows a positive trend. The efficiency of agricultural activities improved. The main condition for the effective development of business activities in rural areas is to take into account their features, the variety of forms, directions and types of activities. Large-scale production of the rural economy does not solve the problems of food supply, unemployment and low living standards of the rural population. The effective functioning of small businesses is one of the main directions of diversification of the rural economy, an important factor in solving the economic and social problems of rural areas in creating the competitive agricultural environment, creating additional jobs in rural areas, improving living standards. The performance of the agrarian economy depends on changing conditions at the macro- and mezo-levels; therefore, constant state support is required to assist agribusinesses in providing auxiliary services for processing industries, alternative types of activities, and supporting innovative activities when implementing new technologies.

\section{References}

1. F.N. Avkhadiev, D.I. Fayzrakhmanov, V.Ya Petrova et al., The concept and methodology of sustainable development of the agro-industrial complex of the Republic of Tatarstan (Kazan State Agrar. Univer., Kazan, 2015) 120 p.

2. F.N. Mukhametgaliev, Agrarian reforms in the Republic of Tatarstan: problems and solutions, Competitiveness in the global world: econ., sci., technol., 3, 4-8 (2014)

3. L.V. Mikhailova, Methodological features of the development planning of small enterprises in agriculture, Competitiveness in the global world: econ., sci., technol., 7(part 4), 100-103 (2017)

4. S.A. Andryushchenko, National and regional mechanisms for implementing the priorities for the development of the production potential of the agrifood complex of Russia, Int. Agricult. J., 2, 34-38 (2019)

5. I.G. Gainutdinov, D.I. Fayzrakhmanov, The development of the social infrastructure of the village and its impact on the economic indicators of agricultural production, Bull. of Kazan State Agrar. Univer., 3, 39-55 (2015)

6. A.R. Battalova, R.S. Tukhvatullin, F.N. Mukhametgaliev, F.F. Mukhametgalieva, Priority areas of development of agricultural entrepreneurship in the regions of the Russian Federation, Int. J. on Emerg. Technol., 10(2), 133-136 (2019)

7. The main indicators of the socio-economic development of the Republic of Tatarstan in 2018, Retrieved from: http://mert.tatarstan.ru/eng/file/ pub/pub_1766102.pdf

8. The socio-economic situation of the Republic of Tatarstan (a comprehensive information and analytical report January-December 2019) no. 12 (Tatarstanstat) $86 \mathrm{p}$.

9. I. Ushachev, The main directions of the Strategy for sustainable socio-economic development of the agro-industrial complex of Russia, Agro-indust. complex: econ., manag., 6, 4-24 (2017)

10. The strategy of socio-economic development of the Republic of Tatarstan until 2030, Retrieved from: http://mert.tatarstan.ru/strategiya-sotsialnoekonomicheskogo-razvitiya.htm

11. N.F. Kashapov, M.M. Nafikov, M.Kh. Gazetdinov et al., Modern problems of digitalization of agricultural production, IOP Conf. Ser. Mater. Sci. and Engineer., 570, 012044 (2019) Retrieved from: https://DOI: 10.1088/1757-899X/570/1/012044

12. N.F. Kashapov, M.M. Nafikov, M. Gazetdinov et al., About one approach to the assessment of technical equipment of agricultural enterprises in 
conditions of economy modernization, IOP Conf. Ser. Mater. Sci. and Engineer., 412, 012038 (2018)

13. D.F. Khafizov, M.M. Khismatullin, Features of the current stage of development of a mixed economy, Bulletin of Kazan State Agrarian University, 3(50), 157-161 (2018)
14. F. Mukhametgaliev, L. Sitdikova, M. Khismatullin, N. Asadullin, L. Mikhailova, Prospects of agricultural business in the Republic of Tatarstan, in: Int. Sci.-Pract. Conf. Agricult. and Food Security: Technol., Innovat., Markets, Human Res. (Kazan, Russia, 13-14 November 2019), Retrieved from: https://doi.org/10.1051/bioconf/20201700059 